\title{
Pheopigment dynamics, zooplankton grazing rates and the autumnal ammonium peak in a Mediterranean lagoon
}

\author{
Yves Collos ${ }^{1 *}$, Julie Husseini-Ratrema ${ }^{1}$, Béatrice Bec ${ }^{1}$, André Vaquer ${ }^{1}$, Thong Lam Hoai ${ }^{1}$, \\ Claude Rougier ${ }^{1}$, Virginie Pons ${ }^{1}$ and Philippe Souchu ${ }^{2}$ \\ ${ }^{1}$ Ecosystèmes lagunaires (UMR CNRS 5119), Université Montpellier II, CC 09334095, Montpellier, Cedex 5, \\ France \\ ${ }^{2}$ Laboratoire côtier DEL, IFREMER, BP 171, , 34203, Sète, Cedex, France \\ *: Corresponding author : Phone: +33-4-6714-4744 Fax: +33-4-6714-3719 Email: collos@univ-montp2.fr
}

\begin{abstract}
The dilution technique was used to estimate chlorophyll and pheopigment, net and gross production as well as zooplankton grazing over a 12-month period in a coastal lagoon in Southern France. Chlorophyll a (Cha) based gross growth rates of phytoplankton ranged from undetectable in February to 2.6 day-1 in June, corresponding to 3.8 divisions per day. Cha-based grazing rates ranged from undetectable in February to $1.1 \mathrm{~d}-1$ in June. The seasonal growth pattern of picoplankton was similar to that of the whole community, with a peak in July, corresponding to four divisions per day. Grazing processes represented from 20 to $150 \%$ of the phytoplankton daily growth, and the grazing pressure was stronger on small phytoplankton cells than on larger cells. Gross growth rates of phytoplankton were related to zooplankton grazing rates, and both were related to water temperature. Mesozooplankton which escaped sampling or oysters had to be also invoked as additional sinks for the primary production. In the fall, pheopigment concentrations greater than chlorophyll concentrations coincided with high ammonium levels in the water column. Pheopigment a production rates were highly correlated to chlorophyll -based microzooplankton grazing rates. The pheopigment a to chlorophyll a ratio was correlated with ammonium concentrations and could be used an index of the balance between ammonium supply (degradation) and demand (uptake by phytoplankton). In addition, pheopigment degradation rates in absence of grazing could be related to irradiance, indicating photodegradation of these compounds.
\end{abstract}

Keywords: phytoplankton - growth - degradation - pheopigments - ammonium - zooplankton 


\section{Introduction}

The application of the so-called "dilution method" (Landry \& Hassett, 1982) has yielded simultaneous data on phytoplankton gross and net growth rates and zooplankton grazing rates over the last 20 years, and has been extremely helpful in furthering our understanding of the balance between phytoplankton source and loss terms. This technique usually involves chlorophyll a as a phytoplankton biomass index, and growth and grazing rates are derived from changes in this variable as a function of dilution (Andersen et al., 1991; Dagg, 1995; Landry et al., 1995; Dupuy et al., 2000; Murrell et al., 2002; Calbet \& Landry, 2004). However, this technique has not been applied to pheopigments so far. As pigment degradation products, pheopigments could give useful indications dealing with the phytoplankton mortality through grazing by zooplankton (Yentsch, 1965; Therriault \& Platt, 1978; Welschmeyer \& Lorenzen, 1985). Still, the use of pheopigments in such studies has been limited by lack of accuracy due to the use of filter fluorometers (Neveux \& deBilly, 1986; Vernet \& Lorenzen, 1987). More recent instruments such as spectrofluorometers or HPLC allow much better estimates of those degradation products which are important in highly productive coastal environments (Neveux et al., 1990). As these pigments are thought to result from both grazing and photo-oxidation processes (Yentsch, 1965; Lorenzen, 1967; Welschmeyer \& Lorenzen, 1985), we applied the dilution technique in order to separate both effects and therefore assess their respective influence on pheopigment concentrations.

Here we report data from an annual cycle which allows a wide variety of environmental conditions to be encountered and tested for their influence on phytoplankton growth and zooplankton grazing rates. In particular, we will focus on the relationship between phytoplankton mortality and the peak in ammonium concentrations occurring in the fall every year in the Thau lagoon (Casellas et al., 1990; Mazouni et al., 1996; Collos et al., 1997; 
Souchu et al., 2001). This work is part of a long term program which aims to describe and understand the functioning of the Etang de Thau lagoon.

\section{Materials and Methods}

The Etang de Thau (Fig. 1) is a large $\left(75 \mathrm{~km}^{2}\right)$ and shallow (4 m mean depth, $10 \mathrm{~m}$ maximal depth) Mediterranean coastal lagoon located in Southern France (43²4'N, $3^{\circ} 36^{\prime}$ E). It is exploited mainly for oyster farming which makes it an important economic area. The sampling station (ZA) was located near oyster pens (see Souchu et al., 2001 for more details).

\section{Physical and chemical variables}

Photosynthetic available radiation (PAR) was measured at the water surface with a LICOR (Model LI-190SA) quantum sensor and a LI-1000 data logger. Underwater irradiance was measured every $50 \mathrm{~cm}$ with a LI-COR (Model 193SA) spherical quantum sensor. The visible light extinction coefficient was calculated from linear regressions of irradiance vs. depth.

Samples for ammonium $\left(\mathrm{NH}_{4}\right)$ determination were immediately fixed and measured in the laboratory using the method of Koroleff (1976). Additional samples for nutrient analyses samples were brought to the field laboratory and frozen. Soluble Reactive Phosphorus (SRP), nitrate $\left(\mathrm{NO}_{3}^{-}\right)$and nitrite $\left(\mathrm{NO}_{2}^{-}\right)$and dissolved reactive silica were analysed with a segmented flow analyser (Tréguer \& Le Corre 1975).

\section{Sampler effect}

Following the results of Price et al. (1986), Chavez \& Barber (1987) and Williams \& Robertson (1989), we modified the samplers used in our laboratory by replacing the toxic 
central rubber spring with a silicone tubing. Surface samples thus collected were incubated and compared to samples collected directly by immersing the polycarbonate (PC) incubation bottle below the surface. While the results were satisfactory for the Niskin bottle, this was not the case for the Van Dorn type bottle which clearly appeared to remain toxic for the organisms under study (Fig. 2). Note that these were surface samples and that the contact time between water samples and the bottle were kept to a minimum (2-3 minutes at most). To our knowledge, this is the first time such a persistent problem is reported for sampling bottles following the change of the central rubber spring.

In order to avoid such potential problems, seawater samples dedicated to growth dynamics/grazing measurements were then collected by directly immersing 20 liter PC containers $10 \mathrm{~cm}$ below the surface. Seawater was then passed through a $1000 \mu \mathrm{m}$ mesh to remove larger debris without removing large diatoms (Price et al., 1985; Collos \& Slawyk, 1986; Dupuy et al., 2000). The PC containers were emptied into a 60 liter polyethylene vat (tested for non toxicity) in order to homogenize the sampled water. Aliquots were then taken to fill duplicate series of one liter PC experimental bottles.

Serial dilution experiments (Landry \& Hassett, 1982) were conducted monthly over a 12 month period. Part of the seawater was gravity filtered via silicone tubing and an in-line, $0.2 \mu \mathrm{m}$ Suporcap (Pall-Gelman) filter (Landry et al., 1995). Each filter capsule was prepared by rinsing with one liter of deionized water and one liter of seawater before use. Final plankton densities were about 14, 24, 48, 71 and 100\% of ambient levels. Nutrient enrichment was made by adding $100 \mu \mathrm{l}$ of $\mathrm{K}$ medium (Keller et al., 1987) at 100 fold concentration. This

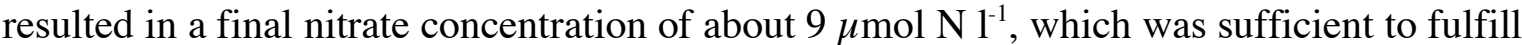
the phytoplankton nutrient requirements over 24 hours in summer (Fouilland et al., 2002). In situ incubations were carried out over 24 hours at $50 \mathrm{~cm}$ below the surface with unfractionated natural populations under full nutrient sufficient conditions (enriched samples) 
and with a duplicate control without nutrient addition (unenriched samples). Pigment contents (chlorophylls $\underline{a}, \underline{b}, \underline{c}$ and pheopigments $\underline{a}, \underline{b}$ and $\underline{\mathrm{c}}$ ) were measured spectrofluorimetrically in acetone extracts as described by Neveux \& Lantoine (1993). The term pheopigments includes both pheophytin and pheophorbide here.

Temporal changes in chlorophyll a (Cha) were used to compute the apparent growth rate $\mathrm{m}(\mathrm{x})$ for each dilution $(\mathrm{x}=1$ for the undiluted sample, and $\mathrm{x}=0$ at infinite dilution):

$$
\mathrm{m}(\mathrm{x}, \mathrm{t})=1 / \mathrm{t} \ln (\mathrm{Cx}, \mathrm{t} / \mathrm{Cx}, 0)
$$

Where $\mathrm{C}(\mathrm{x} ; 0)$ and $\mathrm{C}(\mathrm{x}, \mathrm{t})$ are initial and final concentrations of Cha.

Linear regressions between apparent growth rate and dilution factor (Landry and Hassett, 1982) allow to determine simultaneously the instantaneous growth rate $\mu$ (Y intercept) and the phytoplankton mortality rate by microzooplankton grazing (slope of the line) :

$$
\mathrm{m}(\mathrm{x})=\mu-\mathrm{gx}
$$

where $\mu$ is independent from dilution and is determined in enriched samples.

Post incubation fractionation on Nuclepore filters allowed to isolate the less than $2 \mu \mathrm{m}$ fraction, which is characteristic of Ostreococcus tauri (Courties et al., 1994) and estimate its growth and mortality rates by the dilution technique mentioned above.

Besides being a degradation product of Cha, pheopigment $\underline{a}(\mathrm{~Pa})$ is also an integral part of photosystem (PS) II and is present in proportions of about $4 \%(\mathrm{~Pa} / \mathrm{Cha})$ in non degraded plant systems (Ort, 1986). The calculation of pheopigment gross rate of change must therefore be corrected for any production due to synthesis of PS II components coming from phytoplankton growth during incubation. Such a correction was introduced by using "relative pheopigment values" ( $\mathrm{Pa} / \mathrm{Cha})$ and calculating a "change in relative $\mathrm{Pa}$ " (KrelPa) according to the equation:

KrelPa $=[\ln ((\mathrm{fPa} / \mathrm{fCha}) /(\mathrm{iPa} / \mathrm{iCha}))] / \mathrm{T}$

where $\mathrm{fPa}=$ final pheopigment $\mathrm{a}$ 
fCha: final chlorophyll a

$\mathrm{iPa}=$ initial pheopigment $\mathrm{a}$

iCha $=$ initial chlorophyll a

$\mathrm{T}=$ incubation time.

Then the usual computations were applied in order to obtain an apparent rate of change which was plotted against the dilution factor. The Y intercept was interpreted as the change in pheopigments in absence of grazing.

Zooplankton composition and biomass were analysed before starting the dilution experiment. The sampling was operated by pump from -1 to $-0.5 \mathrm{~m}$ at the same station. The organisms which were collected through a filtering collector of $40 \mu \mathrm{m}$ mesh size, did not suffer any damage, but obviously, individuals less than $40 \mu \mathrm{m}$ (flagellates and aloricate oligotrichs), were not retained in the samples. The plankton material was then fixed in a buffered $4 \%$ formaldehyde solution and slightly coloured with Rose Bengal to obtain the best contrasted image for sorting and image analysis. Monotype sorted individuals were handled with an image analysis routine for counts and measures (Lam-Hoai 1991, Lam-Hoai et al., 1997). According to Mullin (1969) and Omori \& Ikeda (1984), if the specific weight of an animal is close to 1 , it is reasonable to establish the equivalence of its volume to its wet weight $\left(1 \mathrm{~cm}^{3} \approx 1 \mathrm{~g}\right)$. Therefore abundance and wet weight were evaluated per litre, respectively for density (ind $1^{-1}$ ) and biomass ( $\mu$ g wet weight $1^{-1}$ ), from 10 litres of pumped water. 


\section{Results}

\section{Physical and chemical conditions}

Water temperature ranged more than 3 fold over the year (Table 1), with minimum in January $\left(6.5^{\circ} \mathrm{C}\right)$ and maximum in August $\left(25^{\circ} \mathrm{C}\right)$. Mean surface irradiance during the incubation period ranged more than four fold. Salinity ranged from 31.3 in November to 38.8 in April. Inorganic nitrogenous nutrients were generally low excepted for ammonium which attained a peak in October $\left(8.7 \mu \mathrm{mol} \mathrm{N}{ }^{-1}\right)$, and relatively high values in September $(4.9 \mu \mathrm{mol}$ $\left.\mathrm{N}^{-1}\right)$ and November $\left(4.8 \mu \mathrm{mol} \mathrm{N}{ }^{-1}\right)$. Cha ranged more than 10 fold with minimum in November $\left(0.4 \mu \mathrm{g}^{-1}\right)$ and maximum in May $\left(5.4 \mu \mathrm{g} \mathrm{1^{-1 }}\right)$. Pa also ranged more than 10 fold, with minimum in February $\left(0.13 \mu \mathrm{g}^{-1}\right)$ and maximum in October $\left(2.2 \mu \mathrm{g}^{-1}\right)$ when it was almost twice as high as that of Cha. In December, all incubation bottles were lost. Among the nano and microphytoplankton assemblages, the numerically dominant genus was Chaetoceros sp. in April (94.5\%) and May (99.2\%), and Skeletonema costatum in June (85.7\%).

The taxonomic richness and mean abundances of zooplankton individuals larger than $40 \mu \mathrm{m}$ were lower in winter ( 5 taxa, 4 ind $\mathrm{l}^{-1}$ or $3 \mu \mathrm{g} \mathrm{l^{-1 }}$ in February), than in the rest of the year (14 to 23 taxa and 9 to 70 ind $1^{-1}$ or 11 to $39 \mu \mathrm{g} \mathrm{l}^{-1}$ ). The seasonal succession was clearly marked by dominant populations, notably copepod nauplii in February, Tintinnopsis beroidea and Acartia margalefi copepodites in March, copepod nauplii and bivalve veligers in April, Oikopleura dioica and Favella serrata in May and June, Tintinnopsis corniger and copepod nauplii in July, copepod nauplii and bivalve veligers in September and October. With the exception of copepods (Acartia and Oithona), Oikopleura and meroplankton such as ascidian and polychaete larvae, most of the zooplankton belonged to the microzooplankton class size.

Examples of dilution plots are given in Fig. 3. Excepted for February and September, all regressions between the unfiltered fraction and phytoplankton growth were significant and 
they all exhibited a linear relationship. This was also valid for the August 1998 data taken from Dupuy et al. (2000).

Gross growth rates of phytoplankton, as well as net growth rates with and without nutrient enrichment, and grazing rates showed more than 10 fold seasonal variations over the study period (Fig. 4). During winter, and up to early spring, all rates were low and similar (negative to $0.5 \mathrm{~d}^{-1}$ ). In May, differences were clear between a gross phytoplankton growth rate of about $2.1 \mathrm{~d}^{-1}$, lower net rates in enriched samples $\left(1.7 \mathrm{~d}^{-1}\right)$ and net rates without enrichment which were near zero. In summer, differences between rates were greatest, with peaks in gross growth rates around 2.5 to $2.7 \mathrm{~d}^{-1}$, corresponding to $3.6-3.9$ divisions per day, while net growth in enriched samples remained at the level found in late spring $\left(1.5-1.7 \mathrm{~d}^{-1}\right)$. In June, net growth without enrichment was still extremely low (about $0.1 \mathrm{~d}^{-1}$ ) but increased regularly through July $\left(0.8-0.9 \mathrm{~d}^{-1}\right)$ and peaked in September $\left(1.5-1.7 \mathrm{~d}^{-1}\right)$ when all rates became similar again. In October, the situation was back to low rates $\left(0.1-0.4 \mathrm{~d}^{-1}\right)$ with the exception of gross growth rates which presented a secondary peak in November $\left(0.8 \mathrm{~d}^{-1}\right)$. Gross growth rates of the whole fraction and microzooplankton grazing rates are shown in Table 2, with descriptive statistics.

Gross growth rates for the fraction lower than $2 \mu \mathrm{m}$ exhibited a seasonal pattern similar to that of the whole community (Table 2), with a minimum (zero) in February and a peak in July $\left(2.75 \mathrm{~d}^{-1}\right.$, corresponding to 4 divisions. $\left.\mathrm{d}^{-1}\right)$.

In spite of the similarity in shape between seasonal trends in gross growth rates and irradiance during incubation, there was no significant correlation between both variables, but the correlation between gross growth rate and water temperature was significant (Fig. 5, $r=$ $0.834, \mathrm{P}=0.0014)$. In a somewhat similar pattern, zooplankton grazing rates were not related to chlorophyll-a, but were correlated to water temperature $(\mathrm{r}=0.673, \mathrm{P}=0.0233)$, and to phytoplankton gross growth rates. The slope of the regression between growth and grazing 
indicated that micrograzers consumed about $41 \%$ of the phytoplankton daily growth, and grazing was not statistically related to ascidian larvae wet biomass $(r=0.696, n=8, P>0.05)$, but to no other zooplankton group $>40 \mu \mathrm{m}$. Finally, ammonium concentrations were not related to grazing rates, but were significantly related to the $\mathrm{Pa} / \mathrm{Cha}$ ratio $(\mathrm{r}=0.844, \mathrm{n}=11 ; \mathrm{P}$ $=0.0042$ ), with large values of ammonium (Table 1) and $\mathrm{Pa} / \mathrm{Cha}$ ratios (Table 3) in the fall. Initial values of $\mathrm{Pa} / \mathrm{Cha}$ for the whole community ranged from 0.17 in May to 1.86 in October (Table 3), thus representing various stages of phytoplankton degradation, with large values of $\mathrm{Pa} / \mathrm{Ca}$ for both the total and picoplankton fractions in the fall. In the enriched samples of the total fraction, those ratios generally decreased during incubation, except in February, June and November (Table 2), and final Pa/Cha ranged from 0.06 in June to 0.80 in October (100\% bottles). In the controls (data not shown), the ratios generally decreased except in May and June, and final $\mathrm{Pa} / \mathrm{Cha}$ ranged from 0.10 in January to 0.72 in October. Initial values of $\mathrm{Pa} / \mathrm{Cha}$ of picophytoplankton ranged from 0.16 in April to 2.1 in October. In the enriched samples (Table 3), Pa/Cha ratios always decreased during incubation attaining final $\mathrm{Pa} / \mathrm{Cha}$ values from 0.10 in January to 0.96 in October. Estimates of grazing on picophytoplankton were significantly correlated only to ascidian larvae biomass $(\mathrm{r}=0.757, \mathrm{n}$ $=8, \mathrm{p}=0.0296)$.

In absence of grazing ( $\mathrm{Y}$ intercept values of the relationships between relative $\mathrm{Pa}$ changes and dilution), relative Pa changes for the whole phytoplankton community were mostly negative or near zero, indicating degradation of pheopigments during incubation. Maximal negative values were reached in summer, and minima in winter. The relative $\mathrm{Pa}$ changes were related to mean PAR and indicated that photodegradation of $\mathrm{Pa}$ occurred during the incubations (Fig. 6). The photodegradation followed a first-order decay in the range of PAR encountered. 


\section{Discussion}

The maximal phytoplankton growth rate $\left(2.7 \mathrm{~d}^{-1}\right)$ observed in June was close to the highest values recorded with the dilution technique (Murrell et al., 2002). At temperatures above $20^{\circ} \mathrm{C}$, gross growth rates were much higher (up to $70 \%$ ) than those predicted by the model of Eppley (1972), corrected for day length. This discrepancy could be due to unbalanced growth and cell division presenting a time lag relative to pigment synthesis so that cell-based growth estimates are much lower than Cha-based growth estimates (Collos, 1986). The maximum grazing rate of $1.98 \mathrm{~d}^{-1}$ is also in the high range of values recorded by this technique, and is close to the value of $2.11 \mathrm{~d}^{-1}$ observed by Dagg (1995) in an oyster farming site.

For healthy phytoplankton, values of the $\mathrm{Pa} / \mathrm{Cha}$ ratio usually range from 0.05 to 0.10 (Shuman \& Lorenzen, 1975; Barlow et al. 1993; Fundel et al. 1998). The initial values we observed ( 0.17 to 1.86$)$ were greater and indicated a range of physiological state, with heavily degraded populations in October. The general decrease in the $\mathrm{Pa} / \mathrm{Cha}$ ratio during incubation indicates an improvement of the cell status, which was not due to nutrient enrichment because it was also observed in the unenriched controls (Table 3). The only exception was in June when the ratio increased in the 3 least diluted samples. This was probably an artefact already observed by Andersen et al. (1991), which was due to the presence of S. costatum in the samples (Suzuki \& Fujita 1986).

Our results concerning photodegradation of pheopigments (Fig. 6) are similar to those reported by Welshmeyer \& Lorenzen (1985), although in the latter study some grazing activity was present as well as the water was filtered throughout a $10 \mu \mathrm{m}$ mesh "to remove as many grazers as possible" but it must have included some of the microzooplankton community (Taguchi et al., 1993). The first order rate constants $\left(0\right.$ to $\left.0.15 \mathrm{~h}^{-1}\right)$ we found for 
photooxidation (Fig. 6) were within the range of values previously reported (SooHoo \& Kiefer, 1982).

The lack of correlation between ammonium and grazing rates indicate that ammonium is not a direct result of grazers present in the incubation bottles. Other sources of ammonium include anoxia events in summer (Souchu et al., 1998), but no such event occurred during our study. Grazing by large filter feeders such as mesozooplankton, oysters and mussels could certainly release ammonium to the water column at any time of the year. Significant correlations are sometimes found between mesozooplankton biomass and phytoplankton abundance estimates as Cha (Cotano et al., 1998). In our case, the only zooplankton group that exhibited such a relationship was the ascidian larvae $(r=0.941, n=8, p=0.0005)$. The importance of those organisms is probably due to the presence of oyster cultures, where epibionts such as ascidians are abundant. It also suggests that microzooplankton is not the only group responsible for grazing, as often assumed in dilution studies. A recent review of the global impact of microzooplankton grazers on marine phytoplankton indicates that micrograzers consume about $60 \%$ of phytoplankton daily growth in coastal environments (Calbet \& Landry, 2004). In our case, microzooplankton grazing consumes only $41 \%$ of phytoplankton daily growth, so that $59 \%$ must be due to other organisms.

The lack of relationships between the biomass of various groups of mesozooplankton and Pa may indicate that the Pa we measured could be the "suspended Pa" produced by microzooplankton which do not form fast sinking fecal pellets and can be sampled accurately by our sampling procedure (Welschmeyer \& Lorenzen, 1985), although this has been disputed (Conover et al., 1988; Taguchi et al., 1993). This "suspended Pa" is subjected to photodegradation because of its low sinking rate. This possibility is supported by the decreasing trends in $\mathrm{Pa} / \mathrm{Cha}$ during incubation (Table 2) that are independent of nutrient status. They may be an indication of release of grazing pressure from oysters and 
mesozooplankton which are excluded from the bottles during incubation, thereby leading to reduced Pa production.

Ammonium was not correlated to Pa concentrations, as sometimes observed in other environments. For example, Therriault \& Platt (1978) found significant correlations between ammonium and $\mathrm{Pa}$ concentrations in a temperate coastal embayment and suggested a link with grazing activity. In the present study, ammonium concentrations were correlated to the $\mathrm{Pa} /$ Cha ratios, in a way similar to findings by McCarthy \& Kamykowski (1972) in California coastal waters and Litaker et al. (1988) in the Newport River estuary. Lorenzen (1967) found that the $\mathrm{Pa} / \mathrm{Cha}$ ratio was related to the productivity index as well as the copepod/Ca ratio, and suggested that the $\mathrm{Pa} / \mathrm{Cha}$ ratio is a measure of nutrient turnover in the euphotic zone.

Although his assertion was not really supported by his data because the chosen variables were not independent and there was probably a lot of noise due to the methodology used (Neveux \& deBilly, 1986; Vernet \& Lorenzen, 1987), his conclusion could be correct. In our study, the fact that ammonium was related to the $\mathrm{Pa} / \mathrm{Cha}$ ratio rather than $\mathrm{Pa}$ alone suggests that $\mathrm{Pa} / \mathrm{Cha}$ is an indicator of the balance between ammonium source (phytoplankton degradation) and sink (phytoplankton growth). Data from other coastal environments support this assertion (McCarthy \& Kamykowski, 1972; Litaker et al. 1988). Now that reliable estimates of Pa can be obtained (Neveux et al., 1990), the Pa/Cha ratio could be a useful and easily measured indicator of phytoplankton nutritional status in relation to the nitrogen cycle. At least in our case, this ratio indicates a general degradation of the phytoplankton community in the fall.

\section{References}

Andersen, T., A. K. L. Schartau, \& E. Paasche, 1991. Quantifying external and internal nitrogen and phosphorus pools, as well as nitrogen and phosphorus supplied through 
remineralization, in coastal marine plankton by means of a dilution technique. Marine Ecology Progress Series 69: 67-80.

Barlow, R. G., R. F. C. Mantoura, M. A. Gough \& T. W. Fileman, 1993. Pigment signatures of the phytoplankton composition in the Northeastern Atlantic during the 1990 spring bloom. Deep-Sea Research Part II 40: 459-477.

Calbet A.\& M. R. Landry, 2004. Phytoplankton growth, microzooplankton grazing, and carbon cycling in marine systems. Limnology and Oceanography 49: 51-57.

Casellas, C., G. Pena, B. Picot, S. Illes \& J. Bontoux, 1990. Nutrients in Thau lagoon: grouping of contiguous geographical zones. Water Research 24: 1479-1489.

Chavez, F. P.\& R. T. Barber, 1987. An estimate of new production in the equatorial Pacific. Deep-Sea Research 7: 1229-1243.

Collos, Y., 1986. Time-lag algal growth dynamics: biological constraints on primary production in aquatic environments. Marine Ecology Progress Series 33: 193-206.

Collos, Y. \& G. Slawyk, 1986. ${ }^{13} \mathrm{C}$ and ${ }^{15} \mathrm{~N}$ uptake by marine phytoplankton-IV. Uptake ratios and the contribution of nitrate to the productivity of Antarctic waters (Indian Ocean sector). Deep-Sea Research 33: 1039-1051.

Collos, Y, A. Vaquer, B. Bibent, G. Slawyk, N. Garcia \& P. Souchu, 1997. Variability in nitrate uptake kinetics of phytoplankton communities in a Mediterranean coastal lagoon. Estuarine and Coastal Shelf Science 44: 369-375.

Conover, R. J., R. Durvasula, S. Roy \& R. Wang, 1988. Probable loss of chlorophyll-derived pigments during passage through the gut of zooplankton, and some of the consequences. Limnology and Oceanography 31: 878-887.

Cotano, U., I. Uriarte, \& F. Villate, 1998. Herbivory of nanozooplankton in polyhaline and euhaline zones of a small temperate estuarine system (Estuary of Mundaka): seasonal variations. Journal of Experimental Marine Biology and Ecology 227: 265-279. 
Courties, C., A. Vaquer, M. Troussellier, J. Lautier, M. J. Chrétiennot-Dinet, J. Neveux, C. Machado, \& H. Claustre, 1994. Smallest eukaryotic organism. Nature 370: 255.

Dagg, M. J., 1995. Ingestion of phytoplankton by the micro- and mesozooplankton communities in a productive estuary. Journal of Plankton Research 17: 845-857.

Dupuy, C., A. Vaquer, T. Lam-Hoai, C. Rougier, N. Mazouni, J. Lautier, Y. Collos \& S. Le Gall, 2000. Feeding rate of the oyster Crassostrea gigas in a natural planktonic community of the Mediterranean Thau Lagoon. Marine Ecology Progress Series 205:171-184

Eppley, R. W., 1972. Temperature and phytoplankton growth in the sea. Fishery Bulletin 70: 1063-1085.

Fouilland, E., C. Descolas-Gros, Y. Collos, A. Vaquer, P. Souchu, A. Gasc, B. Bibent \& V. Pons, 2002. Influence of nitrogen enrichment on size-fractionated in vitro carboxylase activities of phytoplankton from Thau Lagoon (Coastal Mediterranean Lagoon, France). Journal of Experimental Marine Biology and Ecology 275: 147-171.

Fundel, B., H. B. Stich, H. Schmid \& G. Maier, 1998. Can phaeopigments be used as markers for Daphnia grazing in Lake Constance? Journal of Plankton Research 20: 1449-1462.

Keller, M. D., R. C. Selvin, W. Claus, \& R. R. L. Guillard, 1987. Media for the culture of oceanic ultraphytoplankton. Journal of Phycology 23: 633-638.

Koroleff, F., 1976. Determination of nutrients. In Grasshoff, K. (ed), Methods of Seawater analysis. Verlag Chemie, Weinheim: 117-182.

Lam-Hoai, T., 1991. Zooplankton counted by image analysis and size-frequency distributions in a coastal lagoon. Archiv für Hydrobiologie 121: 147-159.

Lam Hoai, T., C. Rougier \& G. Lasserre, 1997. Tintinnids and Rotifers in a northern mediterranean coastal lagoon. Structural diversity and function through biomass estimations. Marine Ecology Progress Series 152: 13-25. 
Landry, M. R. \& R. P. Hassett, 1982. Estimating the grazing impact of marine microzooplankton. Marine Biology 67: 283-288.

Landry, M. R., J. Kirshtein, \& J. Constantinou, 1995. A refined dilution technique for measuring the community grazing impact of microzooplankton, with experimental tests in the central equatorial Pacific. Marine Ecology Progress Series 120: 53-63.

Litaker, W., C. S. Duke, B. E. Kenney \& J. Ramus, 1988. Diel chl a and phaeopigments in a shallow tidal estuary: potential role of microzooplankton grazing. Marine Ecology Progress Series 47: 259-270.

Lorenzen, C. J., 1967. Vertical distribution of chlorophyll and phaeo-pigments - Baja California. Deep-Sea Research 14: 735- 745.

Mazouni N, J. Gaertner, J. M. Deslous-Paoli, S. Landrein \& M. G. d'Oedenberg, 1996. Nutrient and oxygen exchanges at the water-sediment interface in a shellfish farming lagoon (Thau, France). Journal of Experimental Marine Biology and Ecology 205: 91-113

McCarthy, J. J. \& D. Kamykowski, 1972. Urea and other nitrogenous nutrients in La Jolla Bay during February, March, and April 1970. Fishery Bulletin 70: 1261-1274.

Mullin, M. M., 1969. Production of zooplankton in the ocean: the present status and problems. Oceanography and Marine Biology Annual Review 7: 293-314.

Murrell, M. C., R. S. Stanley, E. M. Lores, G. T. DiDonato, \& D. A. Flemer, 2002. Linkage between microzooplankton grazing and phytoplankton growth in a Gulf of Mexico estuary. Estuaries 25: 19-29.

Neveux, J., \& G. de Billy, 1986. Spectrofluorometric determination of chlorophylls and pheophytins. Their distribution in the western part of the Indian Ocean (July to August 1979). Deep-Sea Research 33: 1-14.

Neveux, J., D. Delmas, J. C. Romano, P. Algarra, L. Ignatiades, A. Herbland, P. Morand, A. Neori, D. Bonin, J. Barbe, A. Sukenik \& T. Berman, 1990. Comparison of chlorophyll and 
phaeopigment determinations by spectrophotometric, fluorometric, spectrofluorometric and HPLC methods. Marine Microbial Food Webs 4: 217-238.

Neveux, J. \& F. Lantoine, 1993. Spectrofluorometric assay of chlorophylls and phaeopigments using the least squares approximation technique. Deep-Sea Research 40:1747-1765.

Omori, M. \& T. Ikeda, 1984. Methods in marine zooplankton ecology. John Wiley and Sons, New York.

Ort, D. R., 1986. Energy transduction in oxygenic photosynthesis: an overview of stucture and mechanism. In Staehelin, L. A. \& C. J. Arntzen (eds), Photosynthesis III. Photosynthetic membranes and light harvesting systems. Encyclopedia of Plant Physiology 19, Springer Verlag, Berlin: 143-196.

Price, N. M., W. P. Cochlan, \& P. J. Harrison, 1985. Time course of uptake of inorganic and organic nitrogen by phytoplankton in the Strait of Georgia: comparison of frontal and stratified communities. Marine Ecology Progress Series 27: 39-53.

Price, N. M., P. J. Harrison, M. R. Landry, F. Azam, \& K. J. F. Hall, 1986. Toxic effects of latex and Tygon tubing on phytoplankton, zooplankton and bacteria. Marine Ecology Progress Series 34: 41-49.

Shuman, F. R. \& C. J. Lorenzen, 1975. Quantitative degradation of chlorophyll by a marine herbivore. Limnology and Oceanography 20: 580-586.

SooHoo, J. B. \& D. A. Kiefer, 1982. Vertical distribution of phaeopigments - I. A simple grazing and photooxidative scheme for small particles. Deep-Sea Research 29: 1539-1551.

Souchu, P., A. Gasc, Y. Collos, A. Vaquer, H. Tournier, B. Bibent \& J. M. Deslous-Paoli, 1998. Biogeochemical aspects of bottom anoxia in a Mediterranean lagoon (Thau, France). Marine Ecology Progress Series 164: 135-146. 
Souchu, P., A. Vaquer, Y. Collos, S. Landrein, J. M. Deslous-Paoli, \& B. Bibent, 2001. Influence of shellfish farming activities on the biogeochemical composition of the water column in Thau lagoon. Marine Ecology Progress Series 218: 141-152.

Suzuki, R. \& Y. Fujita, 1986. Chlorophyll decomposition in Skeletonema costatum: a problem in chlorophyll determination of water samples. Marine Ecology Progress Series 28: 81-85.

Taguchi, S., E. A. Laws \& R. R. Bidigare, 1993. Temporal variability in chlorophyll a and phaeopigments concentrations during incubations in the absence of grazers. Marine Ecology Progress Series 101: 45-53.

Therriault, J. C. \& T. Platt, 1978. Spatial heterogeneity of phytoplankton biomass and related factors in the near-surface waters of an exposed coastal embayment. Limnology and Oceanography 23: 888-899.

Tréguer, P. \& P. Le Corre, 1975. Manuel d'analyse des sels nutritifs dans l'eau de mer, Utilisation de l'AutoAnalyseur II Technicon LOC. Université de Bretagne Occidentale, Brest.

Vernet, M.. \& C. J. Lorenzen, 1987. The presence of chlorophyll b and the estimation of pheopigments in marine phytoplankton. Journal of Plankton Research 9: 255-265.

Welschmeyer, N. A. \& C. J. Lorenzen, 1985. Chlorophyll budgets: zooplankton grazing and phytoplankton growth in a temperate fjord and the Central Pacific Gyres. Limnology and Oceanography 30: 1-21.

Williams, LeB. \& P. J. J. I. Robertson, 1989. A serious inhibition problem from a Niskin sampler during plankton productivity studies. Limnology and Oceanography 34: 13001305.

Yentsch, C. S., 1965. Distribution of chlorophyll and phaeophytin in the open ocean. DeepSea Research 12: 653-666. 
Table 1. Physical, chemical and biological variables at station ZA. August data are taken from Dupuy et al. (2000). N.A.: not available; U: undetectable

\begin{tabular}{|c|c|c|c|c|c|c|c|}
\hline $\begin{array}{l}\text { mean } \\
(\mu \mathrm{mo}\end{array}$ & $\begin{array}{l}\text { mean PAR } \\
\left(\mu \mathrm{mol} \cdot \mathrm{m}^{-2} \cdot \mathrm{s}^{-1}\right)\end{array}$ & $\begin{array}{r}\text { Temperature } \\
\left({ }^{\circ} \mathrm{C}\right)\end{array}$ & \multicolumn{2}{|c|}{$\begin{array}{l}\text { Cha } \mathrm{Pa} \\
\left(\mu \mathrm{g} \cdot \mathrm{l}^{-1}\right)\left(\mu \mathrm{g} \cdot \mathrm{l}^{-1}\right)\end{array}$} & \multicolumn{2}{|c|}{$\begin{array}{l}\mathrm{NO}_{3} \quad \mathrm{NO}_{2} \\
\left(\mu \mathrm{mol} \mathrm{N}^{-1} \mathrm{l}^{-1}\right)\end{array}$} & $\mathrm{NH}_{4}$ \\
\hline 11 February 1999 & 616 & 12.2 & 0.48 & 0.13 & 0.12 & 0.24 & 0.60 \\
\hline 25 March 1999 & 199 & 12.1 & 0.80 & 0.31 & 0.38 & 0.06 & 0.56 \\
\hline 22 April 1999 & 470 & 13.9 & 1.29 & 0.24 & 0.06 & 0.31 & 0.57 \\
\hline 20 May 1999 & 405 & 19.7 & 5.38 & 0.95 & $\mathrm{U}$ & $\mathrm{U}$ & 0.31 \\
\hline 8 June 1999 & 752 & 21.7 & 3.59 & 0.80 & $\mathrm{U}$ & $\mathrm{U}$ & 0.61 \\
\hline 8 July 1999 & 852 & 23.3 & 2.04 & 1.09 & 0.16 & 0.05 & 2.26 \\
\hline 17 August 1998 & 724 & 25.0 & 2.65 & 0.68 & 0.09 & 0.07 & 0.30 \\
\hline 16 September 1999 & 915 & 23.3 & 0.62 & 0.27 & 0.42 & 1.03 & 4.89 \\
\hline 21 October 1999 & 444 & 17.5 & 1.19 & 2.20 & NA & NA & 8.70 \\
\hline 18 November 1999 & 244 & 10.5 & 0.39 & 0.14 & NA & NA & 4.80 \\
\hline 16 December 1999 & 247 & 7.4 & NA & NA & NA & NA & 0.60 \\
\hline 20 January 2000 & 363 & 6.5 & 2.22 & 0.43 & NA & NA & 0.06 \\
\hline
\end{tabular}


Table 2. Gross growth rates $\left(\mu \pm \mathrm{SE}, \mathrm{d}^{-1}\right)$ and microzooplankton grazing rates $\left(\mathrm{g} \pm \mathrm{SE}, \mathrm{d}^{-1}\right)$ based on Cha in enriched samples; $r^{2}$ : coefficient of determination; $n$ : number of observations. Grazing is expressed as a loss term (negative values). The significance level of the regression (i.e. slope, $g$, was significantly different from zero, $\mathrm{p}<0.05$ ) is indicated by $\mathrm{p}$ : ns: non significant, $* \mathrm{p}<0.01, * * \mathrm{p}<0.001, * * * \mathrm{p}<0.0001$. Data for August are taken from Dupuy et al. (2000). Data for enriched samples only.

\begin{tabular}{lccccc}
\hline Date & $\mu$ & $\mathrm{g}$ & $\mathrm{r}^{2}$ & $\mathrm{p}$ value & $\mathrm{n}$ \\
\hline Feb. 99 & $-0.23 \pm 0.06$ & $0.28 \pm 0.10$ & 0.50 & $<0.05$ & 10 \\
Mar. 99 & $0.60 \pm 0.04$ & $-0.17 \pm 0.06$ & 0.51 & $<0.05$ & 10 \\
Apr. 99 & $0.57 \pm 0.02$ & $-0.11 \pm 0.03$ & 0.64 & $*$ & 10 \\
May. 99 & $2.13 \pm 0.06$ & $-0.36 \pm 0.11$ & 0.62 & $<0.05$ & 9 \\
Jun. 99 & $2.63 \pm 0.05$ & $-1.13 \pm 0.08$ & 0.96 & $* * *$ & 10 \\
Jul. 99 & $2.42 \pm 0.05$ & $-0.78 \pm 0.07$ & 0.94 & $* * *$ & 10 \\
Aug. 98 & $2.68 \pm 0.07$ & $-1.46 \pm 0.11$ & 0.95 & $* * *$ & 10 \\
Sep. 99 & $1.65 \pm 0.09$ & $-0.10 \pm 0.15$ & 0.06 & $\mathrm{n} . \mathrm{s}$. & 10 \\
Oct. 99 & $0.39 \pm 0.07$ & $-0.26 \pm 0.11$ & 0.41 & $<0.05$ & 10 \\
Nov. 99 & $0.66 \pm 0.04$ & $-0.28 \pm 0.06$ & 0.74 & $*$ & 9 \\
Jan. 00 & $0.49 \pm 0.02$ & $-0.11 \pm 0.04$ & 0.49 & $<0.05$ & 10 \\
\hline & & & & & \\
\hline
\end{tabular}


Table 3. Pheopigment a/Chlorophyll a ratios in initial samples (range of triplicate values) and in final samples (range of 5 dilution levels) for the total phytoplankton community and the fraction less than $2 \mu \mathrm{m}$ over an annual cycle in Thau lagoon. Data for August are taken from Dupuy et al. (2000). Data for enriched samples only.

\begin{tabular}{|c|c|c|c|c|}
\hline & \multicolumn{2}{|c|}{ Total } & \multicolumn{2}{|c|}{$<2 \mu \mathrm{m}$} \\
\hline & initial & final & initial & final \\
\hline Feb. 99 & $0.26-0.28$ & $0.17-0.37$ & $0.23-0.45$ & $0.12-0.22$ \\
\hline Mar. 99 & $0.36-0.43$ & $0.19-0.35$ & $0.24-0.29$ & $0.14-0.16$ \\
\hline Apr. 99 & $0.18-0.19$ & $0.15-0.17$ & $0.16-0.17$ & $0.17-0.20$ \\
\hline May 99 & $0.17-0.18$ & $0.09-0.12$ & $0.34-0.45$ & $0.12-0.14$ \\
\hline June 99 & $0.21-0.23$ & $0.06-0.72$ & $0.25-0.27$ & $0.12-0.17$ \\
\hline July 99 & $0.52-0.56$ & $0.12-0.21$ & $0.30-0.32$ & $0.11-0.25$ \\
\hline Aug. 98 & $0.24-0.27$ & $0.09-0.21$ & N. D. & N. D. \\
\hline Sept. 99 & $0.39-0.48$ & $0.12-0.19$ & $0.76-0.84$ & $0.20-0.42$ \\
\hline Oct. 99 & $1.82-1.86$ & $0.57-0.80$ & $1.70-2.10$ & $0.73-0.96$ \\
\hline Nov. 99 & $0.35-0.37$ & $0.24-0.51$ & $0.40-0.41$ & $0.26-0.43$ \\
\hline Jan. 00 & $0.19-0.20$ & $0.10-0.16$ & $0.60-0.71$ & $0.11-0.42$ \\
\hline
\end{tabular}


Figure legends

1. Location of the study site. Urban areas in dark.

2. Changes in chlorophyll a (as \% of control) during in situ incubation of surface samples taken with a Van Dorn type sampler relative to samples taken with a polycarbonate (control) bottle. Both series were incubated in polycarbonate bottles.

3. Examples of experimental analyses for dilution experiments conducted at station ZA in Thau lagoon over a yearly cycle. Regression lines are fitted to the data for incubations with added nutrients.

4. Gross and net phytoplankton growth rates $(\mu)$ and zooplankton grazing rates over an annual cycle in Thau lagoon. TA and TB are replicate controls (no dilution and no enrichment), A and B are replicate net growth rates (no dilution but with enrichment). All rates are expressed in units of time ${ }^{-1}$ for comparison. Grazing is expressed as a loss term (negative values).

5. Phytoplankton gross growth rates and zooplankton grazing as a function of water temperature. Grazing is expressed as a loss term (negative values). Dashed line: 95\% confidence limits.

6. Pheopigments changes in absence of grazing (KrelPa) as a function of mean irradiance (PAR) during $24 \mathrm{~h}$ incubations and over an annual cycle in Thau lagoon. Negative values represent losses. Dashed line: 95\% confidence limits. 


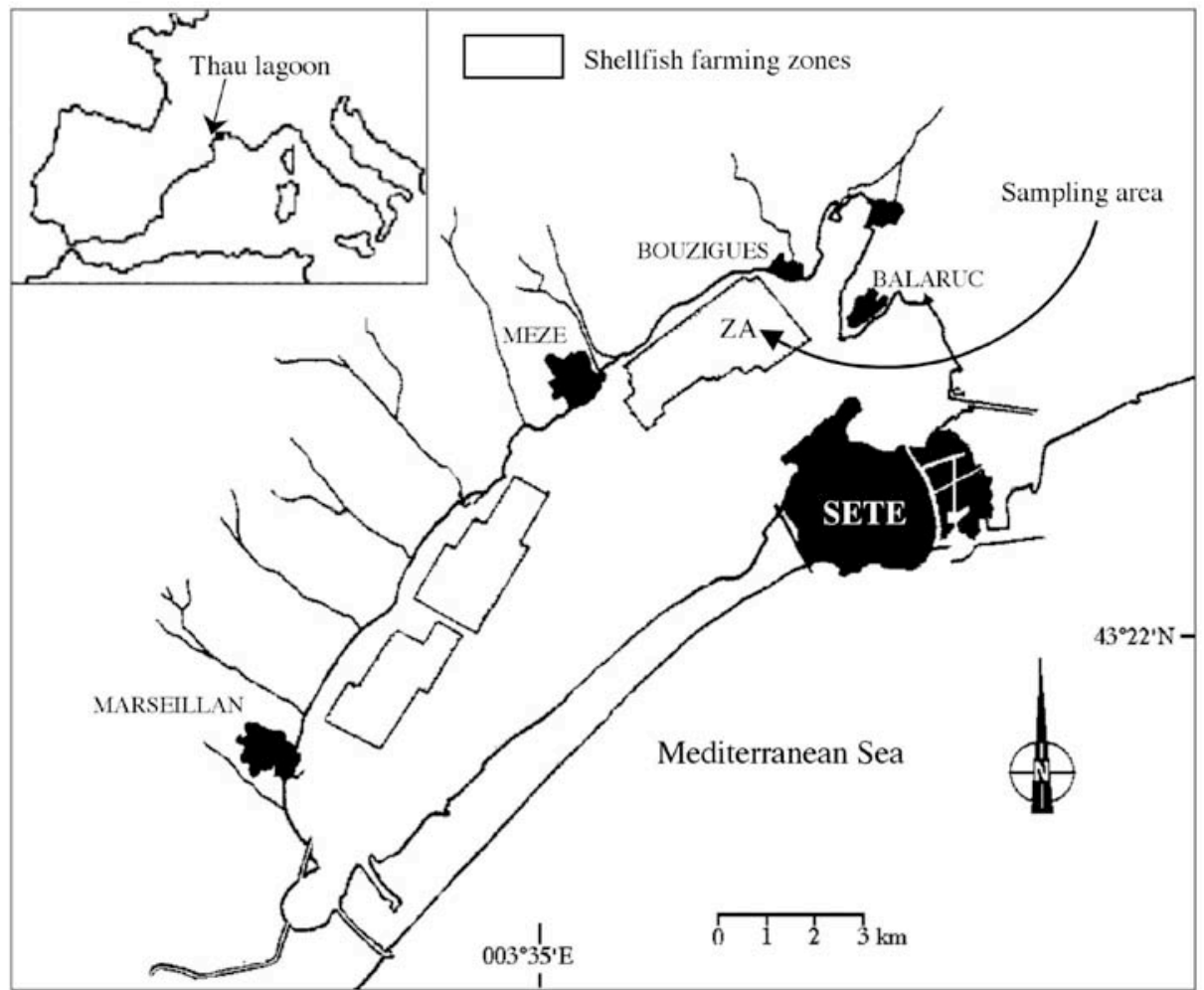

Figure 1 


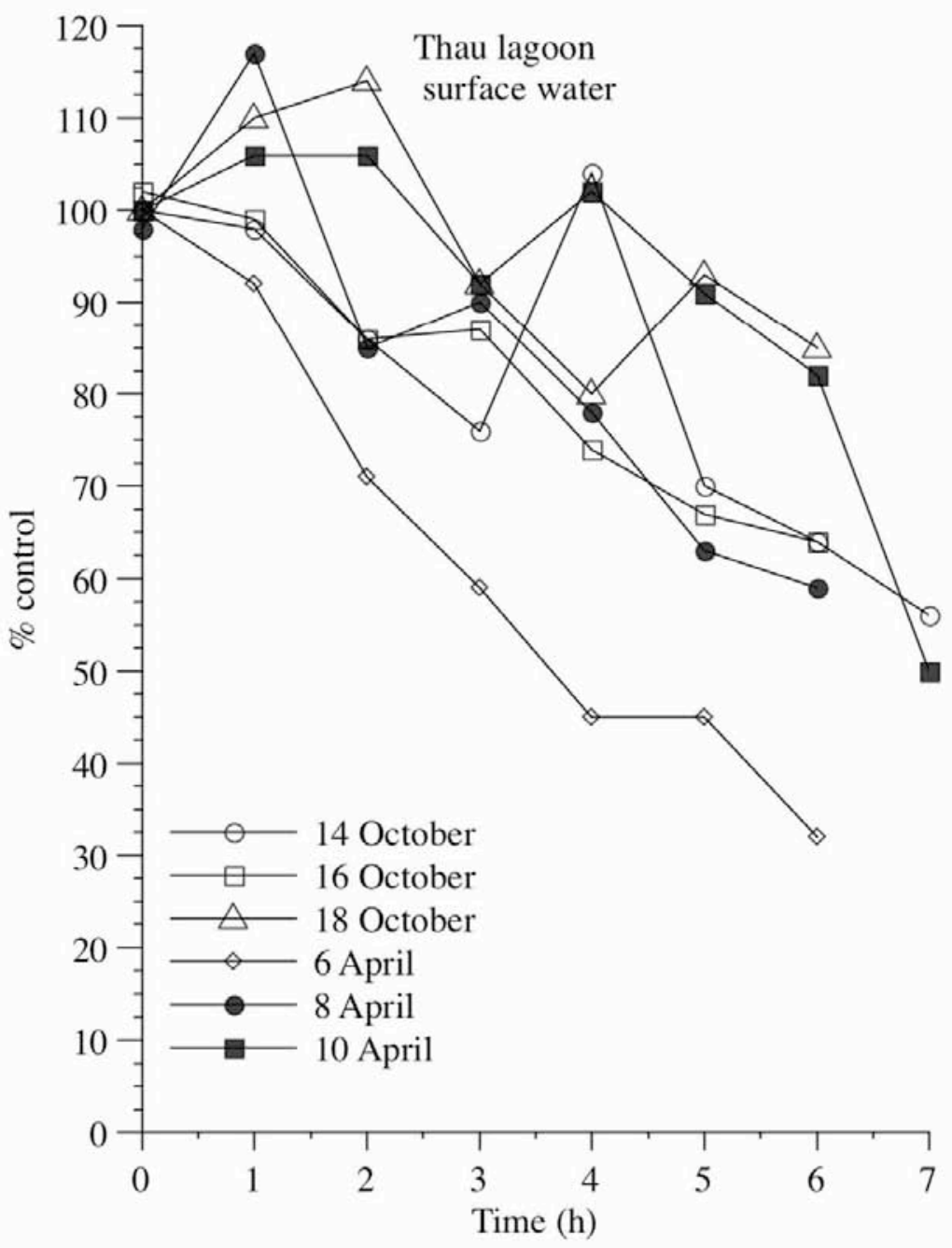

Figure 2 


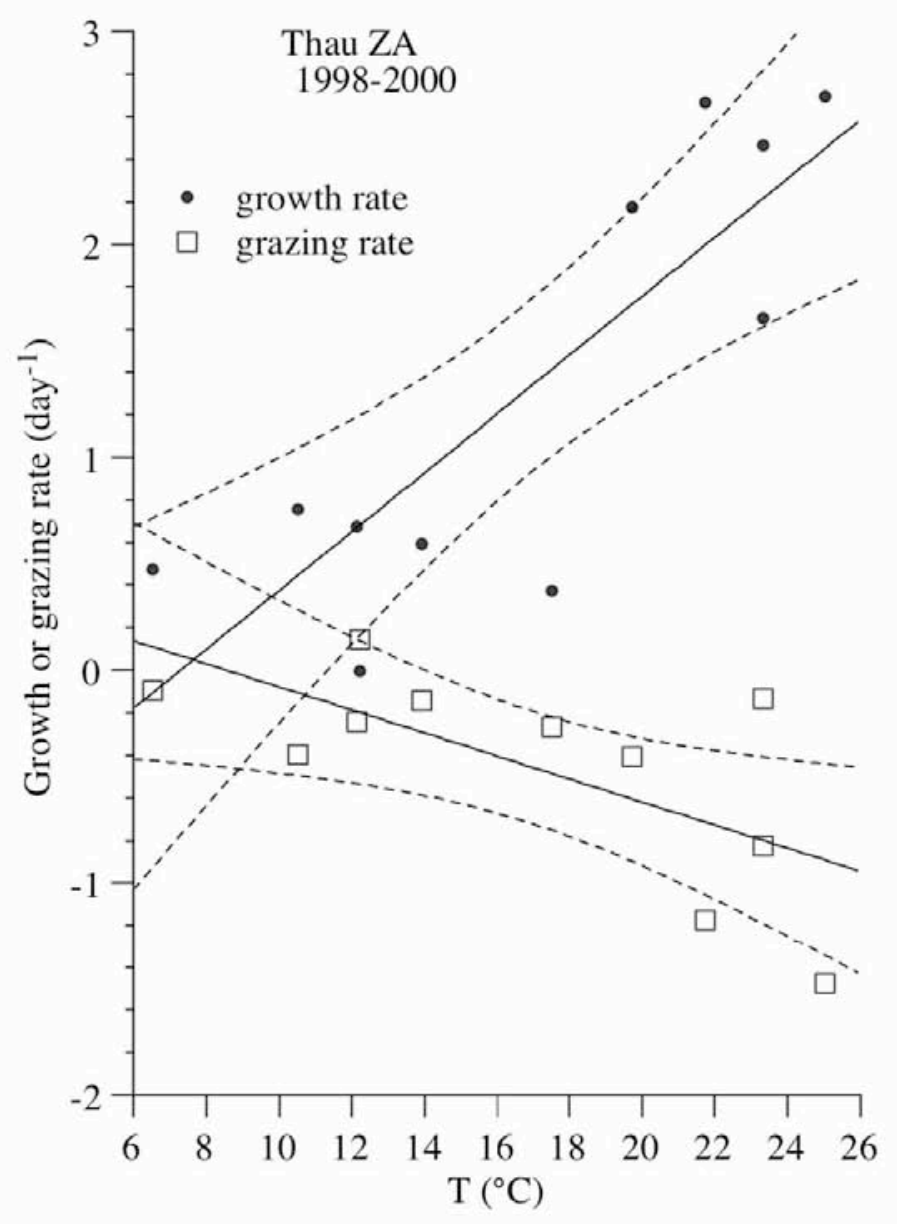

Figure 3 


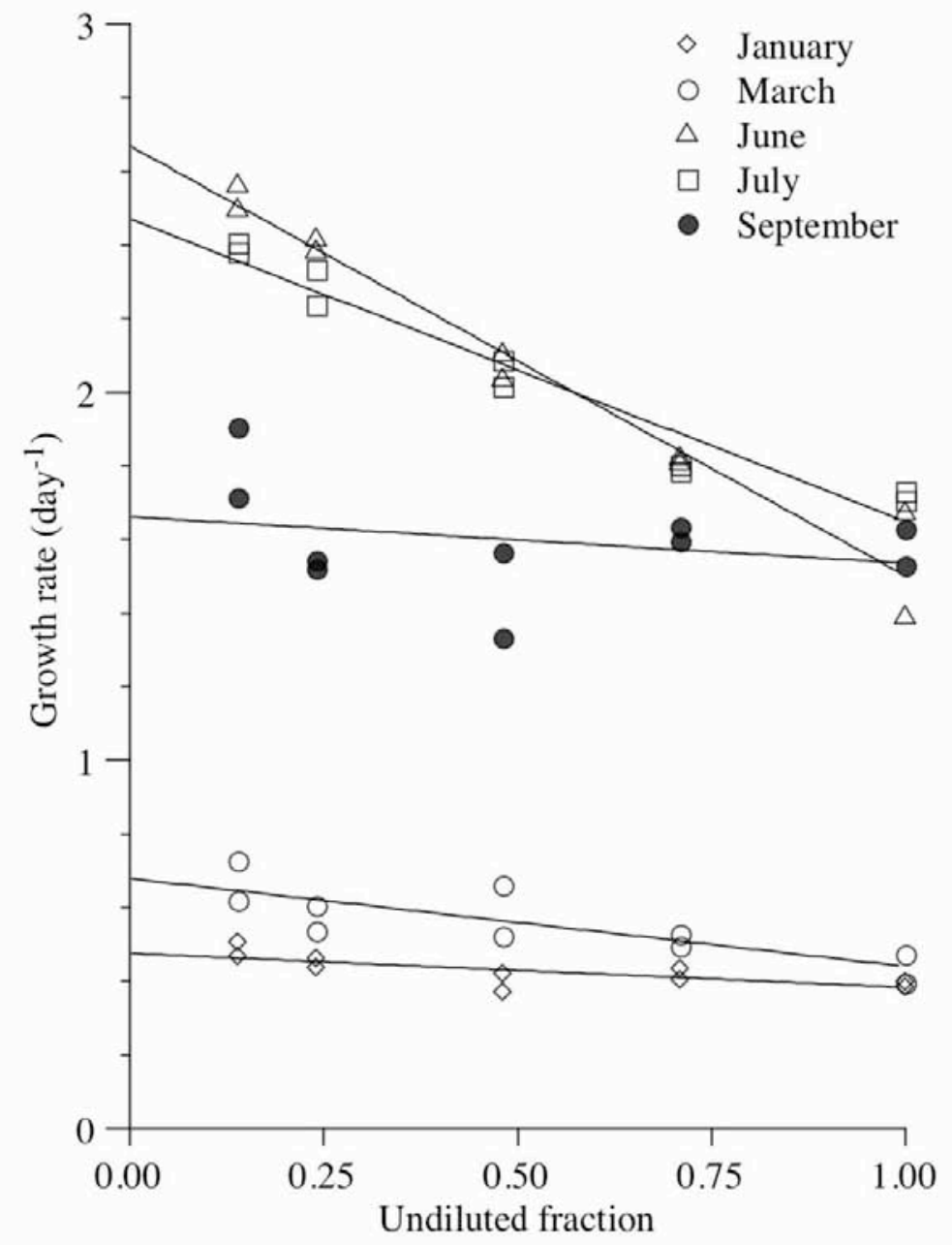

Figure 4 


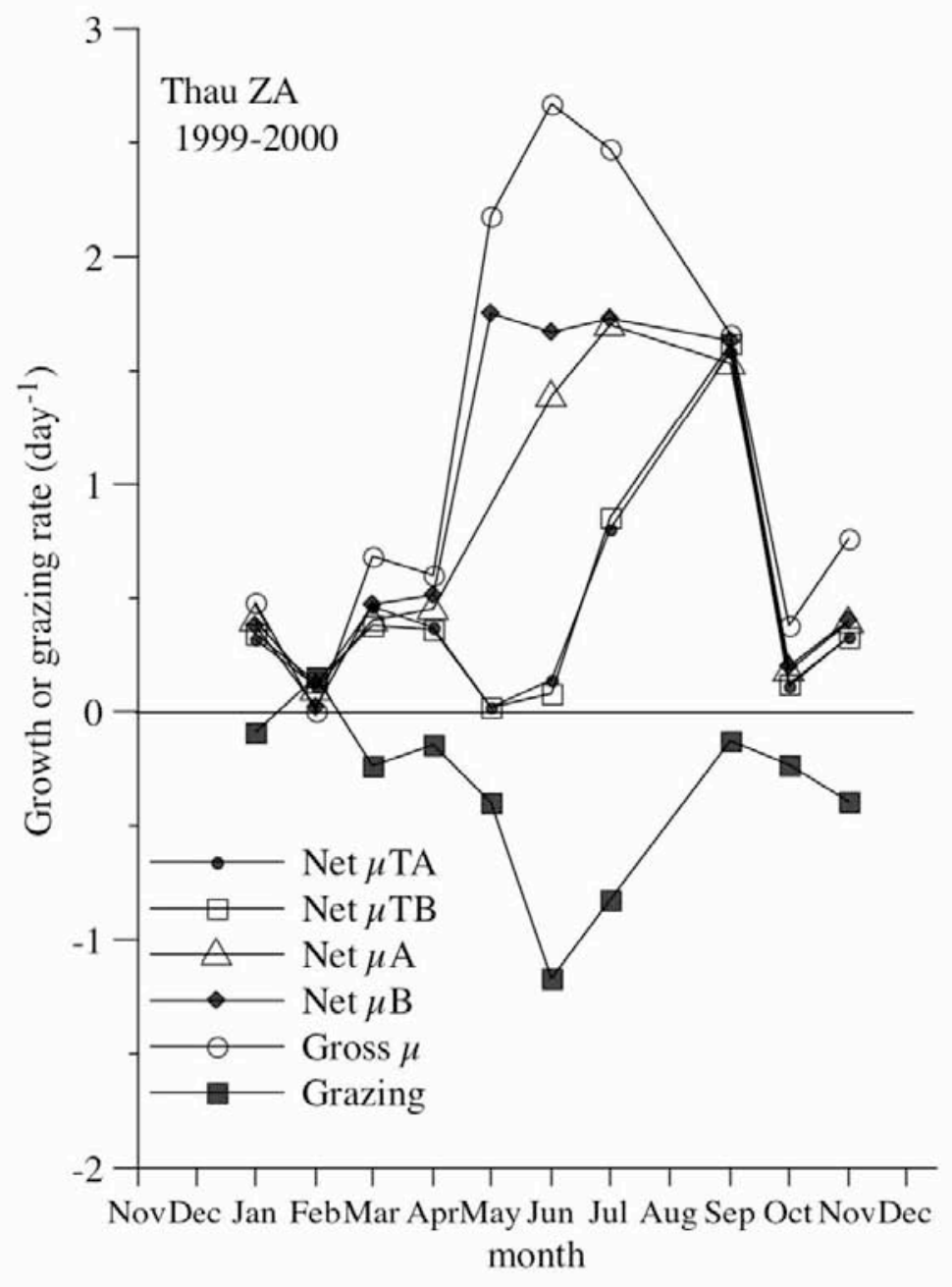

Figure 5 


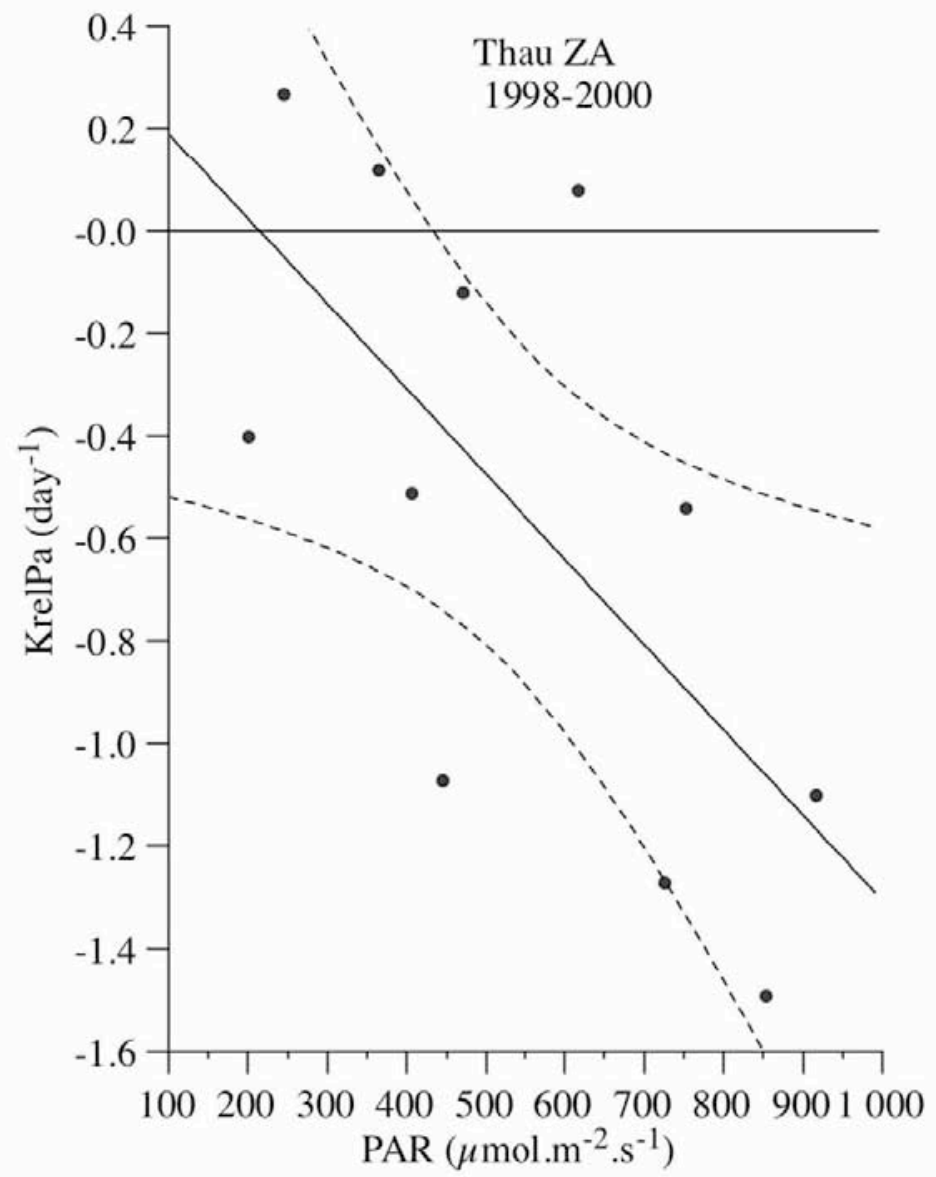

Figure 6 